\title{
Green Synthesis of Silver Nanoparticles Using Flower Extract of Hemigraphis colorata as Reducing Agent and its Biological Activity
}

\author{
Murugan Elangovan ${ }^{1}$, Dhayalan Ramachandran ${ }^{1}$, Krishnan Rajesh ${ }^{2, *}$ \\ 1 Department of Chemistry, Indian Arts and Science College, Tiruvannamalai 606502 \\ 2 Arignar Anna Govt. Arts College, Cheyyar, Tamil Nadu, India 604407 \\ * Correspondence: krisrajesh1977@ gmail.com;
}

Received: 6.01.2021; Revised: 15.03.2021; Accepted: 20.03.2021; Published: 7.05.2021

\begin{abstract}
Green synthesis of silver nanoparticles (Ag NPs) was performed using flower extract of Hemigraphis colorata ( $H$. Colorata). Synthesized nanoparticles were characterized by UV-Visible Spectrophotometer (UV-Vis), Fourier Transform Infrared (FT-IR), Scanning Electron Microscope (SEM), and Transmission Electron Microscope (TEM-SAED). , The crystalline nature of the sample was examined by an X-ray diffraction study (XRD). The UV-Visible spectrum showed surface plasma resonance (SPR) at $360 \mathrm{~nm}$ revealed the formation of nanoparticles, SEM and TEM exhibited spherical shape particles with an average size between $10-20 \mathrm{~nm}$. The valuation of the antibacterial and antifungal study revealed its efficiency in killing bacteria and fungi.
\end{abstract}

Keywords: green synthesis; Hemigraphis colorata; flower extract; antibacterial activity.

(C) 2021 by the authors. This article is an open-access article distributed under the terms and conditions of the Creative Commons Attribution (CC BY) license (https://creativecommons.org/licenses/by/4.0/).

\section{Introduction}

The synthesis of nanoparticles has drawn researchers' attention around the globe due to their size, shape, and properties [1]. Controlling the size and shape of particular causes a drastic change in their properties. The properties of raw materials differ from bulk materials due to their size [2]. Among the many nanoparticles, silver and gold are getting scientists' interest due to their properties and applications [3]. Colloidal Ag NPs have distinctive chemical stability, conductivity, catalytic and bacterial activity [4]. Its applications in various fields of science and technology have been explored due to its physicochemical properties [5]. Silver nanoparticles are non-toxic to human beings and also kill bacteria and fungus [6,7]. Its efficiency has been evaluated in treating burns, wounds, and several bactericidal infections [8-10].

Applications of Ag NPs have been explored in the field of textile [11], cell biology [12], data storage [13], antimicrobial agents [14], drug delivery [15], ointment [16], agriculture, and cosmetics [17], much more application can be found in the literature. The use of toxic and hazardous chemicals to produce Ag NPs produces a risk to the environment, and hence, green methods gained interest to avoid those chemicals to produce the Ag NPs [18, 19]. Common biological materials used in the green synthesis Ag NPs are bacteria, fungi, and plant extracts due to their antioxidant and reducing properties. The water-soluble compounds present in the plant extract are responsible for reducing metal salt into the respective metal nanoparticles [20, 21]. Various parts of the plant extracts have been used as reducing agents for the green synthesis of Ag NPs. Clerodendrum phlomidis [22], Trapa natans [23], and Cleome visosa. L 
[24], Tulsi leaf [25], Phoenix dactylifera [26], Artocarpus intege [27], Cauliflower extract [28], Gymnema sylvestre [29], and Teucrium polium leaf [30] are some of the plant extracts that recently have been used for the fabrication of Ag NPs for various applications.

The present work aims to utilize the flower extract of H.Colorata as green reducing to produce Ag NPs. PlantH. Colorata belongs to the Acanthaceae family [31]. The following bimolecular such as flavonoids, saponins, carboxylic acid, carbohydrate, and other phenolic compounds have been reported in $H$. colorata. This plant possesses many medicinal properties such as healing potential of wonder, bleeding, ulcer and inflammation. It is also used as folk medicine to treat anemia and diabetes[32, 33].

\section{Materials and Methods}

\subsection{Reagents and extract preparation.}

AR grade silver nitrate was purchased from Lobachemie, Mumbai, India. Distilled water was to prepare the solutions. Fresh flowers of $H$. colarata were collected from the local area of power, Tiruvannamalai District, Tamil Nadu, India. The flowers were thoroughly washed with water. About $10 \mathrm{~g}$ of dried flowers was extracted with $100 \mathrm{ml}$ distilled water. The extract obtained was filtered using Whatman filter paper, stored in a refrigerator, and used for green synthesis silver nanoparticles.

\subsection{Synthesis of Ag NPs.}

In a $250 \mathrm{ml}$ beaker, $100 \mathrm{ml}$ of $0.1 \mathrm{~mm}$ silver nitrate solution was taken and placed on a magnetic stirrer. Aqueous flower extract of $H$.Colarata was dropwise added to the silver nitrate solution followed by continuous stirring. The heating process was continued for $30 \mathrm{~min}$ at $85^{\circ} \mathrm{C}$. The formation of Ag NPs was confirmed from the brownish appearances of the solution. The solution was kept on a hot plate for the slow evaporation of water content. The Ag NPs were carefully collected from the beaker and thoroughly washed with distilled water to remove excess extract and unreacted silver nitrate solution. Finally, Ag NPs were washed with acetone to remove organic impurities and used for further characterization.

\subsection{Materials characterization.}

Surface Plasmon Resonance (SPR) of the Ag NPs was recorded using a UV-Visible spectrophotometer (Jasco V-670PC). Functional group analysis of the extract and the Ag NPs was assessed by FT-IR spectrometer (Shimadzu, Japan). Crystalline phase analysis was performed by X-ray diffractometer (Bruker, D8 advance). SEM images of the sample were recorded using a scanning electron microscope (Quantachrome, USA).

\subsection{Antimicrobial assay.}

Antibacterial activity of Ag NPs was carried out by agar well diffusion method according to the method described in the literature [34]. The bacteria used in this study were Escherichia coli, Klebsiella Pneumonia, Salmonella typhi, Pseudomonas aeruginosa, Streptococcus epidermidis, and Staphylococcus aureus. The fungi used were Candida Albicans, Cryptococcus neoformans, Aspergillus niger, Aspergillus flavus, Aspergillus fumigates, and Penicillium notatum. Bacterial isolates were suspended in brain Heart Infusion and diluted to $10^{6} \mathrm{CFC}$ per $\mathrm{ml}$. A sterile core borer was used to cut wells with a five $\mathrm{mm}$ 
diameter. Various concentrations of Ag NPs were prepared using DMSO and poured into the wells. The plates were incubated at $37^{\circ} \mathrm{C}$ for $48 \mathrm{~h}$. The zone of inhibition was measured in $\mathrm{mm}$ diameter. DMSO solvent was used as a control, and ciprofloxacin was used as a reference substance.

\section{Results and Discussion}

\subsection{UV-Vis study.}

Fig. 1 shows the UV-Visible spectrum of green synthesized Ag NPs. The spectrum renewal of the absorption at $439 \mathrm{~nm}$ due to the Surface Plasmon Resonance (SPR) color change of the reaction mixture after adding $H$. Colorata extract to the Silver Nitrate solution was observed as dark brown [35]. , The collective oscillation of free electrons in particles is responsible for the color change. The SPR peak centered at $439 \mathrm{~nm}$, indicating silver nitrate reduction into metallic silver [28].

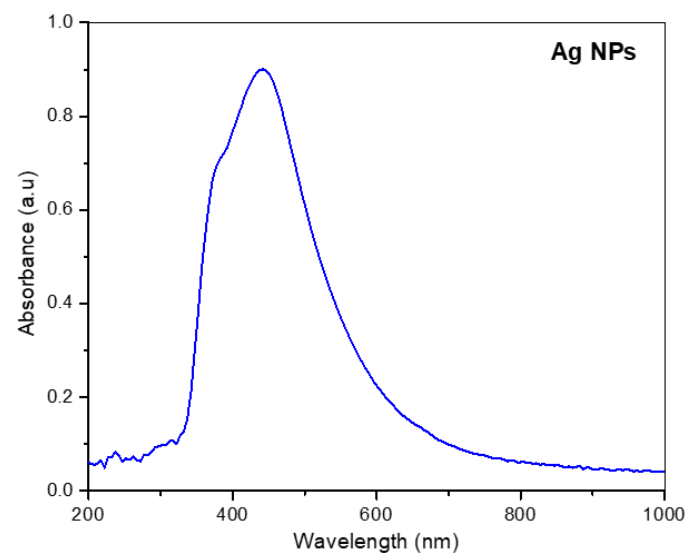

Figure 1. UV-Visible spectrum of green synthesized Ag NPs-H. Colorata extract.

\subsection{FTIR studies.}

Fig. 2 (a) shows the FTIR spectrum of green synthesized Ag NPs. Broadbands obtained at $3402 \mathrm{~cm}^{-1}$ indicate $\mathrm{OH}$ stretching vibration of phenolic compounds. It reveals the presence of phenolic acids or flavonoids. The absorption band noticed at 1635 and $1433 \mathrm{~cm}^{-1}$ arising due to carbonyl (CO) groups [36]. The narrow bands at 1113, 870, 682, and $602 \mathrm{~cm}^{-1}$ attributed to glycoside and substituted phenolic compounds present in the Ag NPs [37].

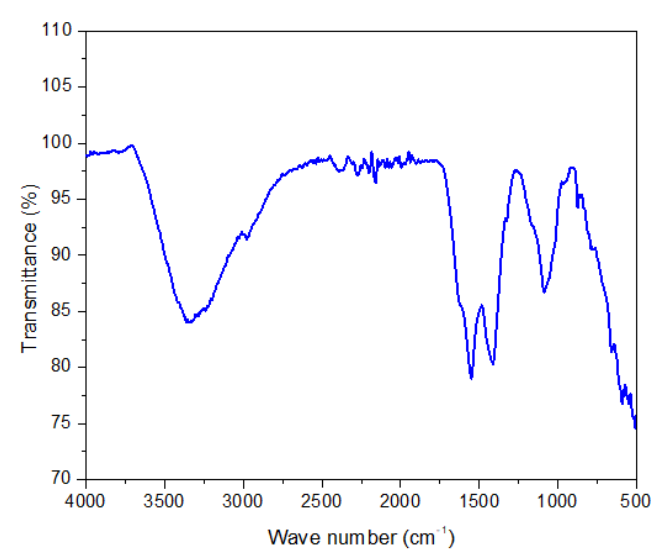

Figure 2a. FTIR spectrum of Ag NPs-Extract. 


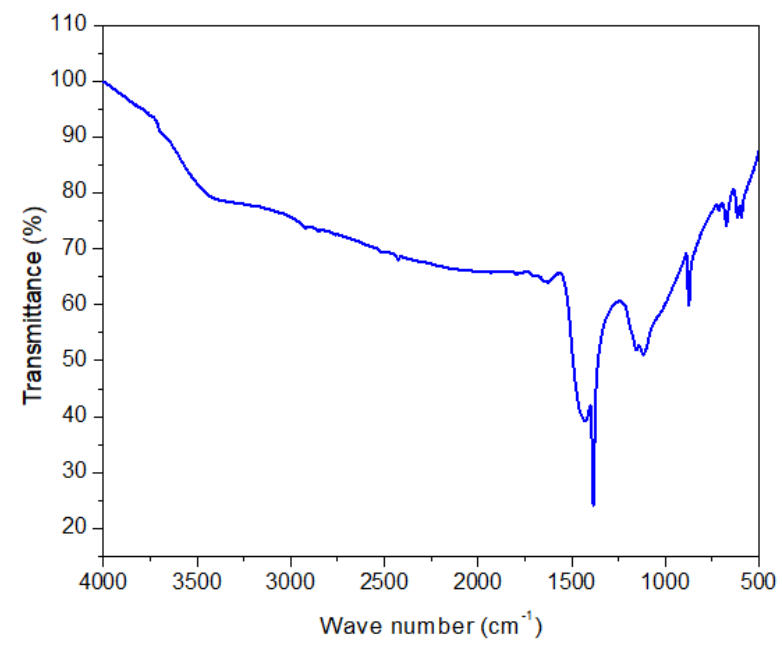

Figure 2b. FTIR spectrum of aqueous extract of $H$. colorata.

FTIR results confirmed the presence of bioactive molecules in the $H$. Colorata flower extract (Fig. 2 (b)). The primary phytochemical screening shows that the flower extract of $H$. Colorata is rich in phenol, carbohydrates, steroids, saponins, coumarins, tannins, proteins, carboxylic acid and flavonoids, xantho proteins and alkaloids [31].

\subsection{XRD study.}

The crystalline phase of Ag NPs synthesized using flower extract of $H$. coralata was investigated using XRD technique (Fig. 3). The Ag NPs was shown clear peaks of cubic phases (JCPDS No. 87-0720) at $2 \theta$ values of $38.13,44.49,64.68,77.39$ and 81.53 corresponds to (1 1 1), (2 00 0), (2 20 ), (3 11 1) and (222) planes. Thus the XRD pattern proved to be strong evidence favoring the UV-Visible spectra and TEM images for the presence of silver nanocrystals. The average crystallite size of the particle calculated using Debye-Scherrer's equation was $14 \mathrm{~nm}$. The XRD results of Ag NPs synthesized using flower extract of foenum-graecum Hance extract, and Allium ampeloprasum $L$ leaf extract showed similar confirming the crystalline silver formation $[38,39]$.

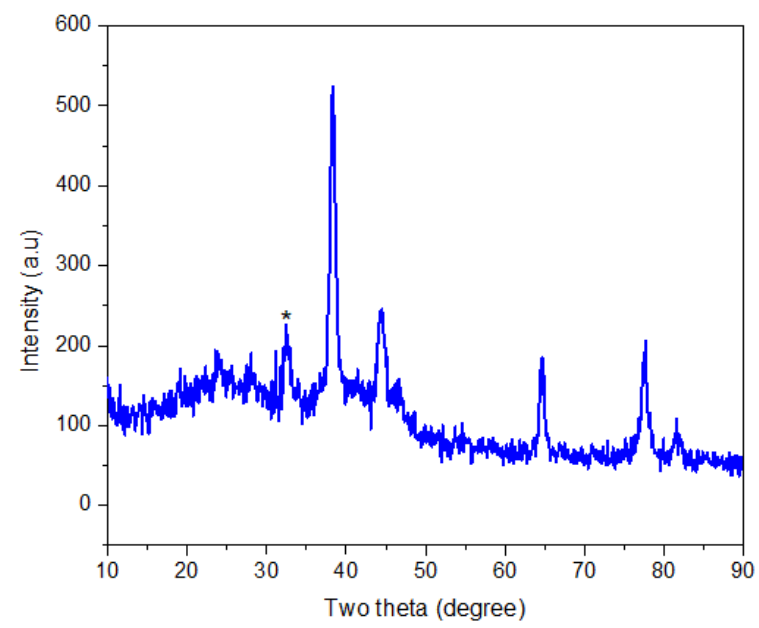

Figure 3. XRD spectrum of Ag NPs synthesized using $H$. colorata.

\subsection{SEM and TEM morphology study.}

Fig. 4 shows the SEM images of $H$. colorata extract stabilized Ag NPs at different magnifications. The results illustrate that the synthesized Ag NPs are spherical. The particles 
have well-defined borders around their edges. The boundary between particles in the SEM image areas shows the role of flower extract as a capping agent.

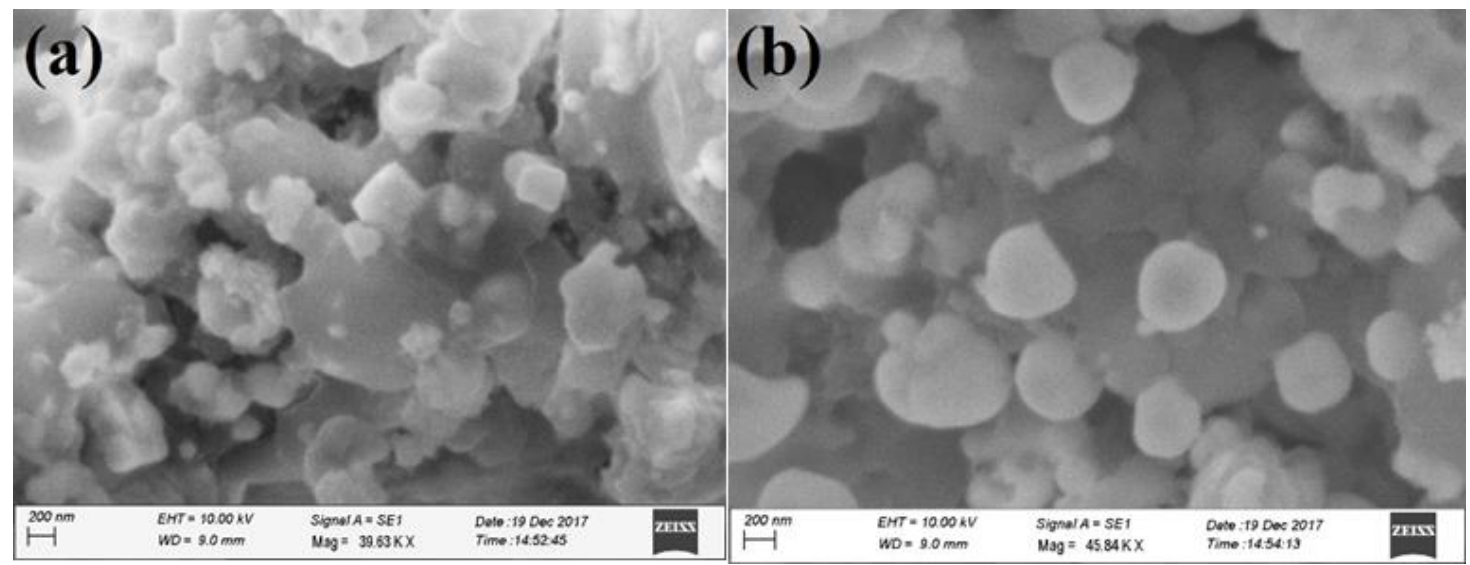

Figure 4. SEM images of Ag NPs synthesized using $H$. colorata flower extract (a) and (b) reveals the spherical shape of the particles at $200 \mathrm{~nm}$ magnification.

TEM images of the green synthesized Ag NPs are shown in Fig. 5. As shown in this figure, most of the nanoparticles are found to be spherical. This finding further supports the UV-Vis, XRD, and SEM results. The average size of the particles measured using software (Image J) is in the range of 10-20 nm. The surface morphology of the Ag NPs was studied from the TEM images. Spherical shape particles observed in the TEM images additionally confirmed the results of SEM analysis. The selected area diffraction pattern (SAED) reveals the crystalline nature of the green-synthesized Ag NPs.

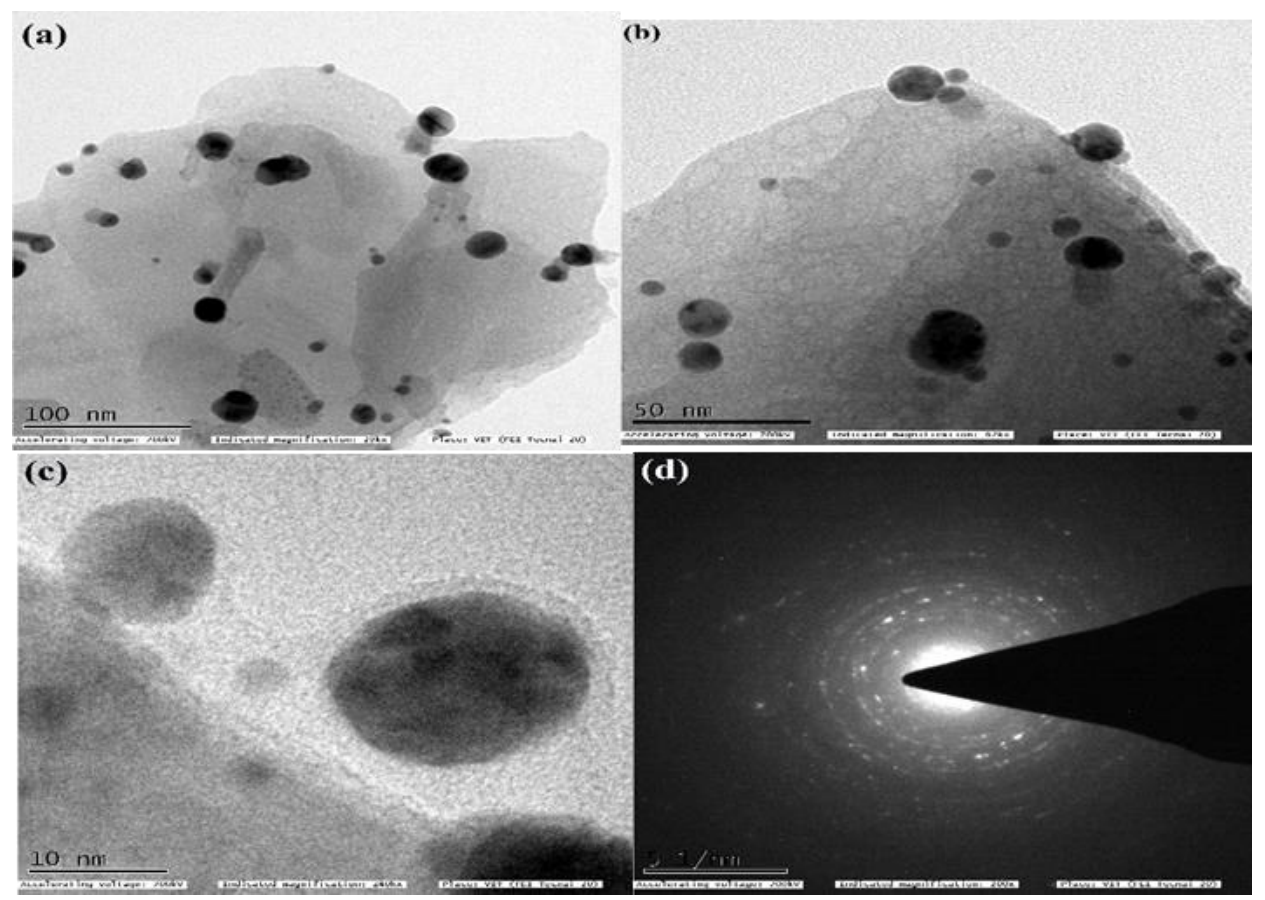

Figure 5. TEM images of Ag NPs synthesized using $H$. coralata flower extract. Images (a), (b), and (c) shows the spherical shape morphology of Ag NPs at 100, 50, and $10 \mathrm{~nm}$ magnifications. (d) Shows the selected area diffraction pattern of Ag crystals.

\subsection{Antibacterial activity.}

Antibacterial and antifungal activity of green-synthesized Ag NPs was tested against pathogenic bacteria and fungi ; the zone of inhibition shown by the bacteria and fungi is 
presented in Table 1. Ciprofloxacin was used as a reference substance. The zone of inhibition shown by the synthesized Ag NPs found to be slightly better than the flower extract. However, the zone of inhibition shown by the bacteria is found to be lower than the ciprofloxacin. Among the tested bacterial, S. typhi and S.epidermidis showed lesser activity. Other bacteria E. coli, K.pneumoniae, P.aeruginosa, and S. aureus showed more or less similar activity. H. Colorata flower extract did not show any activity against tested fungi.

Table 1. Zone of Inhibition of Ag NPs, H. colorata* against bacteria and fungi.

Zone of Inhibition (mm)

\begin{tabular}{|c|c|c|c|c|c|c|c|}
\hline Bacteria & $\begin{array}{c}\text { H.C. } \\
\text { flower } \\
\text { extract }\end{array}$ & $\begin{array}{c}\text { Ag } \\
\text { NPs }\end{array}$ & Ciprofloxacin & Fungi & $\begin{array}{c}H . C^{*} \\
\text { flower } \\
\text { extract }\end{array}$ & $\begin{array}{c}\text { Ag } \\
\text { NPs }\end{array}$ & Ciprofloxacin \\
\hline Escherichia coli & $10 \pm 2$ & $13 \pm 2$ & $28 \pm 4$ & Candida albicans & - & $8 \pm 2$ & $12 \pm 3$ \\
\hline $\begin{array}{l}\text { Klebsiella } \\
\text { pneumoniae }\end{array}$ & $12 \pm 2$ & $14 \pm 2$ & $30 \pm 5$ & $\begin{array}{c}\text { Cryptococcus } \\
\text { neoformans }\end{array}$ & - & $7 \pm 2$ & $13 \pm 2$ \\
\hline Salmonella typhi & $6 \pm 2$ & $6 \pm 2$ & $23 \pm 3$ & Aspergillus niger & - & $8 \pm 2$ & $12 \pm 2$ \\
\hline $\begin{array}{l}\text { Pseudomonas } \\
\text { aeruginosa }\end{array}$ & $14 \pm 3$ & $15 \pm 3$ & $9 \pm 2$ & Aspergillus flavus & - & $6 \pm 2$ & $13 \pm 3$ \\
\hline $\begin{array}{l}\text { Streptococcus } \\
\text { epidermidis }\end{array}$ & $7 \pm 2$ & $7 \pm 2$ & $30 \pm 4$ & $\begin{array}{l}\text { Aspergillus } \\
\text { fumigatus }\end{array}$ & - & $5 \pm 2$ & $13 \pm 3$ \\
\hline $\begin{array}{l}\text { Staphylococcus } \\
\text { aureus }\end{array}$ & $12 \pm 3$ & $14 \pm 3$ & $20 \pm 4$ & $\begin{array}{l}\text { Penicillium } \\
\text { notatum }\end{array}$ & - & - & $13 \pm 2$ \\
\hline
\end{tabular}

However, Ag NPs exhibit lesser antifungal activity against C.albicans, C. neoformans, A. niger, A.flavus, A. fumigates, and P. notatum. Green-synthesized Ag NPs were found to be less effective against all microorganisms tested, and this activity depends on the magnitude of nanoparticles [40]. In fact, spherical Ag NPs contain a larger surface area. However, all the tested bacteria and fungi showed lesser activity compared with standard substances.

\section{Conclusions}

Ag NPs were successfully synthesized using the flower extract of $H$. colorata as a green reducing agent. The characterization methods confirmed the formation of Ag NPs. Crystalline of Ag NPs exhibit moderate toxicity against pathogenic bacteria and fungi. It is well known that $H$. Colorata extract is a source of phenolic and flavonoid compounds. It is believed that the water-soluble compounds present in the $H$. Colorata flower extract are played as reducing as well as stabilizing agents. The methodology and extract used to synthesize spherical shape nanoparticles are identified as an appropriate method to control the particles' size and shape.

\section{Funding}

This research received no external funding.

\section{Acknowledgments}

The authors thank VIT University for providing facilities for spectral characterization techniques. 


\section{Conflicts of Interest}

\section{The authors declare no conflict of interest.}

\section{References}

1. Roy, A.; Bulut, O.; Some, S.; Mandal, A.K.; Deniz Yilmaz, M. Green synthesis of silver nanoparticles: biomolecule-nanoparticle organizations targeting antimicrobial activity. RSC Advances2019, 9, 2673-2702, https://doi.org/10.1039/C8RA08982E.

2. Kuppusamy, P.; Yusoff, M. M.; Maniam, G.P.; Govindan, N. Biosynthesis of metallic nanoparticles using plant derivatives and their new avenues in pharmacological applications-An updated report. Saudi Pharmaceutical Journal2016, 24, 473-484, https://doi.org/10.1016/j.jsps.2014.11.013.

3. Pirtarighat, S., Ghannadnia, M.; Baghshahi, S. Green synthesis of silver nanoparticles using the plant extract of Salvia spinosa grown in vitro and their antibacterial activit assessment. Journal of Nanostructre in Chemistry2019, 9, 1-9, https://doi.org/10.1007/s40097-018-0291-4.

4. Sengottaiyan, A.; Mythili, R.; Selvakumar, T.; Aravinthan, A.; Kamala Kannan, S.; Manoharan, K.; Thiyagrajan, P.; Govarthanan, M.; Kim, J.-H. Green synthesis of silver nanoparticles using Solanum indicum L. and their antibacterial, splenocyte cytotoxic potentials. Research Chemical Intermediates 2016, 42, 30953103, https://doi.org/10.1007/s11164-015-2199-7.

5. Luis, C.-H.; Karla, A.-A.; Jeisson, U.-Á.; Laura, V.-F.; Gabriela Montes de O.-V.; José Roberto, V.-B. Green Synthesis of Gold and Silver Nanoparticles from Plant Extracts and Their Possible Applications as Antimicrobial Agents in the Agricultural Area. Nanomaterials2020, 10,https://doi.org/10.3390/nano10091763.

6. $\quad$ Iris, X.Y.; Jing, Z.; Irene, S.Z.; May, L.M.; Quanli, L.; Chun, H.C. The Antibacterial Mechanism of Silver Nanoparticles and Its Application in Dentistry. International Journal of Nanomedicine2020, 15, 2555-2562, https://doi.org/10.2147/IJN.S246764.

7. Zaki, S.; El Kady, M.F.; Abd-Ei-Haleem, D. Biosynthesis and structural characterization of silver nanoparticles from bacterial isolates. Materials Research Bulletin2011, 46, 1571-1576, https://doi.org/10.1016/j.colsurfb.2013.02.004.

8. Raut, R. W.; Mendhulkar, V. .; Kashid, S.B. Photosensitized synthesis of silver nanoparticles using Withania somnifera leaf powder and silver nitrate. Journal of Photochemistry and Photobiology B: Biology 2014, 132, 45-55, https://doi.org/10.1016/j.jphotobiol.2014.02.001.

9. Pooja, M.; Hemali, P.; Sumitra, C. Biosynthesis of silver nanoparticles formation from Caesalpinia pulcherrima stem metabolites and their broad spectrum biological activities. Journal of Genetic Engineering and Biotechnology2018, 16, 105-113, https://doi.org/10.1016/j.jgeb.2017.09.028.

10. Balaz, M.; Daneu, N.; Balazova, L.; Dutkova, E.; Tkacikova, L.; Briancin, J.; Vargova, M.; Balazova, M.; Zorkovska, A.; Balaz, B. Bio-mechanochemical synthesis of silver nanoparticles with antibacterial activity. Advanced Powder Technology2017, 28, 3307-3312, https://doi.org/10.1016/j.apt.2017.09.028.

11. Loo, Y.Y.; Rukayadi, Y.; Nor-Khaizura, M.-A.-R.; Kuan, C.H.; Chieng, B.W.; Nishibuchi, M.; Radu, S. In Vitro Antimicrobial Activity of Green Synthesized Silver Nanoparticles Against Selected Gram-negative Food borne Pathogens. Frontier in Microbiology2018, 9, https://doi.org/10.3389/fmicb.2018.01555.

12. Abdal Dayem, A.; Hossain, M.K.; Lee, S.B. The role of reactive oxygen species (ROS) in the biological activities of metallic nanoparticles. International Journal Molecular Science 2017, 18,https://dx.doi.org/10.3390\%2Fijms18010120.

13. Kaur, R.; Singh, J.; Tripathi, S. Incorporation of inorganic nanoparticles into an organic polymer matrix for data storage application. Current Applied Physics2017, 17, 756-762, https://doi.org/10.1016/j.cap.2017.02.011.

14. Rautela, A.; Rani, J.; Debnath (Das), M. Green synthesis of silver nanoparticles from Tectona grandis seeds extract: characterization and mechanism of antimicrobial action on different microorganisms. Journal of Analytical Science and Technology2019, 10,https://doi.org/10.1186/s40543-018-0163-z

15. Basu, S.; Samanta, H. S.; Ganguly, J. Green synthesis and swelling behavior of Ag-nanocomposite semiIPN hydrogels and their drug delivery using Dolichos biflorus Linn. Soft Materials2015,16, 7-19, https://doi.org/10.1080/1539445X.2017.1368559.

16. Carabineiro, S. Applications of gold nanoparticles in nanomedicine: recent advances in vaccines. Molecules2017, 22,https://doi.org/10.3390/molecules22050857.

17. Fukui, H. Development of new cosmetics based on nanoparticles. In: Nanoparticle Technology Handbook. Naito, M.; Yokoyama, T.; Hosokawa, K.; Nogi, K. editors. $3^{\text {rd }}$ ed. Elsevier; 2018; pp. 845-877, https://doi.org/10.2147/IJN.S200254.

18. Vinay, S.P.; Chandrasekhar, N.; Udayabhanu.; Nagarju, G.; Chandrappa, C.P.Ixora coccinea extractmediated green synthesis of silver nanoparticles: Photodegradative and antimicrobial studies. International Journal of Biosensors \& Bioelectronics 2019, 5, 100-105, https://doi.org/10.15406/ijbsbe.2019.05.00161.

19. Ahmed, R.H.; Mustafa, D.E. Green synthesis of silver nanoparticles mediated by traditionally used medicinal plants in Sudan.International Nano Letters 2020, 10, 1-14, https://doi.org/10.1007/s40089-019-00291-9. 
20. Shaban, S.M.; Aiad, I.; El-Sukkary, M.M.; Soliman, E.A.; El-Awady, M.Y. One step green synthesis of hexagonal silver nanoparticles and their biological activity. Journal of Industrial and Engineering chemistry2014, 20, 4473-4481, https://doi.org/10.1016/j.jiec.2014.02.019.

21. Sankar, R. Karthik, A.; Prabu, A.; Karthik, S.; Shivashangari, K.S.; Ravikumar, V. Origanum vulgare mediated biosynthesis of silver nanoparticles for its antibacterial and anticancer activity. Colloids and Surfaces B: Biointerfaces 2013, 108, 80-84, https://doi.org/10.1016/j.colsurfb.2013.02.033.

22. Sriranjani, R.; Srinithya, B.; Vellingiri, V.; Brindha, P.; Anthony, S.P.; Sivasubramanian, A.; Muthuraman, M.S. Silver nanoparticle synthesis using Clerodendrum phlomidis leaf extract and preliminary investigation of its antioxidant and anticancer activities. Journal of Molecular Liquids 2016, 220, 926-930, https://doi.org/10.1016/j.molliq.2016.05.042.

23. Saber Saber, M.M.; Mirtajani, S.B.; Karimzadeh, K. Green synthesis of silver nanoparticles using Trapa natans extract and their anticancer activity against A431 human skin cancer cells. Journal of Drug Delivery Science and Technology 2018, 47, 375-379, https://doi.org/10.1371/journal.pone.0216496.

24. Lakshmanan, G.; Sathiyaseelan, A.; Kalaichelvan, P.T.; Murugesan, K. Plant-mediated synthesis of silver nanoparticles using fruit extract of Cleome viscosa L. assessment of their antibacterial and anticancer activity. Karbala International Journal of Modern Science2018, 4, 61-68, https://doi.org/10.1016/j.kijoms.2017.10.007.

25. Singh, J.; Mehta, A.; Rawat, M.; Basu, S. Green synthesis of silver nanoparticles using sun dried tulsi leaves and its catalytic application for 4-Nitrophenol reduction. Journal of Environmental Chemical Engineering2018, 6, 1468-1474, https://doi.org/10.1016/j.jece.2018.01.054.

26. Oves, M.; Aslam, M.; Rauf, M.A.; Qayyum, S.; Qari, H.A.; Khan, M.S.; Alam, M.Z.; Tabrez, S.; Pugazhendhi, A.; Ismail, I.M.I. Antimicrobial and anticancer activities of silver nanoparticles synthesized from the root hair extract of Phoenix dactylifera. Material Science and Engineering C2018, 89, 429-443, https://doi.org/10.1016/j.msec.2018.03.035.

27. Majeed, S.; Bakhtiar, N.F.B.; Danish, M.; Ibrahim, M.N.M.; Hashim, R. Green approach for the biosynthesis of silver nanoparticles and its antibacterial and antitumor effect against osteoblast MG-63 and breast MCF7 cancer cell lines. Sustainable Chemistry and Pharmacy2019, 12, https://doi.org/10.1016/j.scp.2019.100138.

28. Oda, A.M.; Abdulkadhim, H.; Jabuk, S.I.A.; Hashim, R.; Fadhil, I.; Alaa, D.; Kareem, A. Green synthesis of silver nanoparticle by cauliflower extract: characterisation and antibacterial activity against storage. IET Nanobiotechnology 2019, 13, 530-535, https://doi.org/10.1049/iet-nbt.2018.5095.

29. Gomathi, M.; Prakasam, M.; Rajkumar, P.V.; Rajeshkumar, S.; Chandrasekaran, R. Anbarasan, P.M. Green synthesis of silver nanoparticles using Gymnema sylvestre leaf extract and evaluation of its antibacterial activity. South African Journal of Chemical Engineering2019, 32, 1-4, https://doi.org/10.1016/j.sajce.2019.11.005.

30. Hashemi, S.F.; Tasharrofi, N.; Mahmoudi Saber, M. Green synthesis of silver nanoparticles using Teucrium polium leaf extract and assessment of their antitumor effects against MNK45 human gastric cancer cell line. Journal of Molecular Structure2020, 1208,https://doi.org/10.1016/j.molstruc.2020.127889.

31. Anitha, V.T.; Antonisamy, J.M.; Jeeva. S. Antibacterial studies on Hemigraphis colorata (Blume) H.G. Hallier and Elephantopus scaber L. Asian Pacific Journal of Tropical Medicine2012, 5, 52-57, https://doi.org/10.1016/s1995-7645(11)60245-9.

32. Firdhouse, M.J.; Lalitha, P. Biosynthesis of silver nanoparticles using the extract of Alternanthera sessilisantiproliferative effect against prostate cancer cells. Cancer Nanotechnology2013, 4, 137-143, https://doi.org/10.1007/S12645-013-0045-4.

33. Ajitha, B.; Kumar Reddy, Y.A.; Jeon, H.-J.; Ahn, C.W. Synthesis of silver nanoparticles in an eco-friendly way using Phyllanthus amarus leaf extract: Antimicrobial and catalytic activity. Advanced Powder Technology2018, 29, 86-93, https://doi.org/10.1016/j.apt.2017.10.015.

34. Elango, M.; Deepa, M.; Subramanian, R.; Saraswathy, G. Synthesis, structural characterization and antimicrobial activities of polyindole stabilized $\mathrm{Ag}-\mathrm{Co}_{3} \mathrm{O}_{4}$ nanocomposite by reflux condensation method. Materials Chemistry and Physics 2018, 216, 305-315, https://doi.org/10.1016/j.matchemphys.2018.05.049

35. Subramanian, R.; Subbramaniyan, P.; Raj, V. Antioxidant activity of the stem bark of Shorea roxburghii and its silver reducing power. SpringerPlus2013, 2,https://doi.org/10.1186/2193-1801-2-28

36. Bethu, M.S.; Netala, V.R.; Domdi, L.; Tartte, V.; Janapala, V.R. Potential anticancer activity of biogenic silver nanoparticles using leaf extract of Rhynchosia suaveolens: an insight into the mechanism. Artificial cells, nanomedicine, and biotechnology2018, 46, https://doi.org/10.1080/21691401.2017.1414824.

37. Salehi, S. Shandiz, S.A.S.; Ghanbar, F.; Darvish, M.R.; Ardestani, M.S.; Mirzaie, A.; Jafari, M. Phytosynthesis of silver nanoparticles using Artemisia marschalliana Sprengel aerial part extract and assessment of their antioxidant, anticancer, and antibacterial properties. International Journal Nanomedicine 2016, 11, https://doi.org/10.2147/ijn.s99882.

38. Widsanusan, C.; Phattaraporn, C.; Juthaporn, S.; Thearum, R.; Phichaya, K.; Pitak, N.; Too, C.O. Green synthesis and stabilization of silver nanoparticles using Lysimachia foenum-graecum Hance extract and their antibacterial activity. Green Processing and Synthesis2020, 9, https://doi.org/10.1515/gps-2020-0012. 
39. Khoshnamvand, M.; Huo, C.; Liu, J. Silver nanoparticles synthesized using Allium ampeloprasum L. leaf extract: characterization and performance in catalytic reduction of 4-nitrophenol and antioxidant activity. Journal of Molecular Structure2019, 1175, 90-96, https://doi.org/10.1016/j.molstruc.2018.07.089.

40. Ahmad, S.; Munir, S.; Zeb, N.; Ullah, A.; Khan, B.; Ali, J.; Bilal, M.; Omer, M.; Alamzeb, M.; Salman, S. M.; Ali, S. Green nanotechnology: a review on green synthesis of silver nanoparticles-an ecofriendly approach. International Journal of Nanomedicine2019, 14, 5087-5107, https://doi.org/10.2147/IJN.S200254. 